\title{
LAKE VAN BASIN URARTIAN PERIOD ROAD ROUTES SURVEY: FIRST PRELIMINARY REPORT (2017-2018): MURADIYE AND TUŞBA DISTRICTS
}

\author{
Bilcan GÖKCE* - Rıfat KUVANÇ** - Bülent GENÇ***
}

\author{
$\ddot{O} z$ \\ Van Gölü Havzası Urartu Dönemi Yol Güzergahları Yüzey Araştırması \\ Ön Raporu (2017-2018): Muradiye ve Tuşba İlçeleri
}

Urartu Krallığı, M.Ö. 9. yüzylın ortalarından 6. yüzyıl başlarına kadar Doğu Anadolu Bölgesi başta olmak üzere Kuzeybatı İran, Nahçıvan ve Ermenistan'ı içine alan coğrafyda yaklaşık iki yüz elli yıl boyunca siyasi, askeri ve ekonomik anlamda gücünü hisettirmiştir. Engebeli coğrafyası ve sert iklim koşularına rağmen Urartular merkeziyetçi devlet yönetimiyle bölgeye hakim olmuşlardır. Bulundukları coğrafyada hemen hemen her alanda başarı gösteren Urartular bu başarılarını ulaşımda da göstermiştir. Dönemin yazılı kaynakları başta olmak üzere arkeolojik kalıntılardan Urartular'da yol güzergâhlarının önemli bir yerinin olduğu görülmektedir. Tuşba ve Muradiye ilçelerinde gerçekleştirilen yüzey araştırması kapsamında Urartular'ın kuzeye devam ederek Muradiye Ovası'na ulaşan krali bir güzergahının varlı̆̆ı ön plana çıkmaktadır. Yine aynı şekilde Muradiye Ovasına ulaşan bir diğer hat ise Karasu Vadisi güzergahıdır. Kuzeybatı İran'da Urartu Krallığı'nın hakimiyetini sağlayan bir diğer hat ise Van'ın Özalp ilçesi üzerinden İran sınırlarını aşarak Hoy ve Salmas'a ulaşan Doğu Yolu güzergahıdır. Krali ana güzergahların yanı sıra krallık boyunca şekillenen ve derin vadiler boyunca devam eden hatlar ise Urartular'ın hakim oldukları bölgeleri bir güvenlik ağı ile kuşattıklarını ortaya koymaktadır.

Anahtar Kelimeler: Yol, Urartu, Kale, Muradiye, Tuşba.

\footnotetext{
* Assoc. Prof., Iğdır University, Faculty of Science and Letters, Department of Art History, Iğdır/TURKEY. E-mail: bilcan.g@gmail.com. ORCID: 0000-0003-1213-7752

** Asst. Prof., Iğdır University, Faculty of Science and Letters, Department of Art History, Iğdır/TURKEY. E-mail: rifatkuvanc@yahoo.com. ORCID: 0000-0003-0198-8754

*** Asst. Prof., Mardin Artuklu University, Faculty of Letters, Department of Archaeology, Mardin/TURKEY. E-mail: bulendgenc@hotmail.com. ORCID: 0000-0001-9328-1339

${ }^{* * * *}$ We thank Dr. G. Bike Yazıcıoğlu for providing editorial assistance with English translation and proofreading.

(Makale Gönderim Tarihi: 27.10.2020 - Makale Kabul Tarihi: 27.05.2021)
} 


\title{
Bilcan GÖKCE - Rlfat KUVANÇ- Bülent GENÇ
}

\begin{abstract}
For about two-hundred-fifty years between the mid- $9^{\text {th }}-$ early $6^{\text {th }}$ centuries $\mathrm{BC}$, the Urartian Kingdom established its hegemony in Eastern Anatolia and the neighboring regions of Northwestern Iran, Nakhchivan, and Armenia, as the most influential political, military, and economic power of its time. Despite the rugged geography and rough climatic conditions of this mountainous terrain, the Urartu thrived by developing a centralized administrative state apparatus. Urartu excelled in many areas of state-building, including road networks. Particularly textual sources and supporting archaeological evidence demonstrate the importance of road networks for the Urartian state. Surveys in Tushba and Muradiye districts have allowed us to identify the main route of the northern capital road, which continues north and reaches Muradiye Plain, and an alternative northern route that follows the Karasu Stream valley towards Muradiye Plain. An eastern route, which enabled the kingdom to exert control in Northwestern Iran, goes through Özalp district of Van province across the modern border to Iran and reaches Hoy and Salmas. These alternative and auxiliary routes along deep canyons that developed over time suggest that the Urartian state had established an intricate security web in its dominion.
\end{abstract}

Keywords: Roads, Urartu, Fortress, Muradiye, Tushba.

\section{Introduction}

During the $9^{\text {th }}-7^{\text {th }}$ centuries BC, the Urartu established a powerful kingdom with its administrative core located in Van Plain in Eastern Anatolia and expanded its rule over the neighboring regions of Northwestern Iran, Nakhchivan, and Armenia. This highland region is characterized by a rugged topography with high mountain ranges dissected by deep canyons, fast-flowing streams, and intermontane lakes. ${ }^{1}$ While the contemporary Neo-Assyrian Empire reigned over the vast plains of Mesopotamia in the south, the Urartu had to develop a settlement system that is well-adapted to the rough terrain of its dominion. Distinct from the large cities of the southern plains, the Urartian settlement model consisted of hilltop settlements featuring one or two fortresses, built on the foothills of mountains overlooking agricultural plains connected to one another by intermontane valleys. Additionally, watchtowers and outposts were built at strategic locations with commanding views of important mountain passes and valleys. Since its establishment in the mid- $9^{\text {th }}$ century BC onwards, the Urartian Kingdom led a expansionist military policy. Archaeological remains of many fortresses and hilltop settlements indicate that transportation routes were an important instrument, which the Urartian state mobilized in order to exert its political authority over this mountainous terrain.

Although the mountainous topography of Lake Van Basin and its vicinity was a challenge to grapple with for the kingdom, at the same time, this rough terrain constituted an impenetrable natural defense system against the kingdom's enemies. However, while the inaccessibility of this highland zone aided in its defense, it also imposed limitations on the economic capacity and sustainability of settlements through long, harsh winters. For this reason, Urartian kings regularly engaged in military campaigns to adjacent regions in order to sustain the economic basis of the kingdom. Urartian inscriptions

${ }^{1}$ Barnett 1982, pp. 322-328; Zimansky 1985. 
inform us about Urartian kings' annual military campaigns, which departed from Van Plain where the capital city Tushpa (Van Fortress) was established. ${ }^{2}$ Additionally, although limited in number, cuneiform tablets and bullae found at Urartian centers in the peripheral regions of the kingdom indicate that routes between peripheral centers played an important role in maintaining economic stability by ensuring the regular transportation of goods. ${ }^{3}$ Military campaigns were an important economic source for the kingdom, providing captives to be recruited as labor force for royal construction projects and agricultural works, iron for making tools and weapons, and prestige metals such as gold and silver. To ensure the safe and steady flow of material and human resources, the kingdom needed a reliable and wellcontrolled transportation network across the mountains.

Extant archaeological and epigraphic evidence allows us to reconstruct the administrative and cultural borders of the Urartian Kingdom throughout its historical development. In its formative period, the kingdom ruled over Lake Van Basin and its immediate vicinity. Fortresses at Lower Anzaf, Upper Anzaf, Zivistan, Kevenli, Kalecik, Körzüt, and Aznavurtepe located in Van Plain were built in the formative period of the kingdom in order to establish political authority in this region. During the $8^{\text {th }}-7^{\text {th }}$ centuries BC, the kingdom grew more powerful and continued to undertake an efficient program of construction projects. Arin-berd (Erebuni) and Armavir-Blur (Argištihinili) fortresses in Yerevan Plain, Toprakkale (Rusahinili) fortress in Van Plain, and Çavuştepe (Sardurihinili) fortress in Gürpınar Plain are examples of royal construction projects of this period. Especially during the reign of king Rusa, son of Argishti, the construction program of the Urartu attained an ambitious scale with the construction of large-scale fortresses at Karmir-Blur (Teišebai URU), Ayanis (Rusahinili Eiduru-kai), Adilcevaz Kef (Haldie kur Ziuquni?), and Bastam (Rusa-i URU.TUR). ${ }^{4}$ The geographical distribution of these centers not only allows us to reconstruct the extent of the kingdom's territories, but they also help us identify the transportation networks connecting them. The network of identifiable routes suggests that the Urartian communication and transportation networks served mainly military and defensive purposes. The presence of a systemic network of trade routes in the Urartian Period is debatable. ${ }^{5}$

Systematic investigations of Urartian road networks have remained rather limited. ${ }^{6}$ Archaeological remains typically associated with ancient roads of the Persian and Roman periods, such as stone-paved roads or engineered infrastructural works, are virtually absent from the Urartian Period. A stone-paved road across Bingöl Mountains constitutes the only archaeological remains of a road associated with the Urartian Kingdom by researchers. ${ }^{7}$ The remains of this stone-paved road continue for about $90 \mathrm{~km}$ between Bingöl and Elazı̆g varying between $3.90-5.40 \mathrm{~m}$ in width. However, this road is attributed to the Urartian Kingdom solely on the basis of a number of "road stations"

\footnotetext{
${ }^{2}$ Iş̧1k 2015.

${ }^{3}$ Salvini 2001, p. 286 / CB Ay-17; CTU IV.

${ }^{4}$ Zimansky 2005.

${ }^{5}$ Zimansky 1985, pp. 2-3.

${ }^{6}$ Sevin 1989; Belli 2002; Dan 2018.

${ }^{7}$ Sevin 1989.
} 
that consist of multi-room buildings with a square plan along its route. ${ }^{8}$ The main objective of our survey project is to identify the auxiliary routes of the Urartian road network in the core region of the kingdom in the vicinity of Van province by documenting Urartian Period archaeological remains, such as fortresses, inscriptions, and rock tombs located along these routes. Lake Van Basin, which constitutes the administrative royal core of the kingdom, is the key region from which the road network originates. For this reason, 2017-2018 investigations primarily focused on Tuşba and Muradiye districts for the identification of northern and northwestern routes originating from the kingdom's capital at Tuşpa. This report presents our preliminary observations on the archaeological sites documented in this survey area.

\section{Methodology}

In 2017 - 2018, “Archaeological and Epigraphic Investigations of Urartian Period Transportation Routes in Lake Van Basin Survey Project" was conducted under the official permit granted by the Ministry of Culture and Tourism of the Republic of Turkey (permit number 156537; issued on 02.08.2017). In 2017, surveys in Tuşba and Muradiye districts of Van province lasted from September 5 until September 18. The project was financially supported by Van Yüzüncü Y1l University (project number SHD-2017-6114) and the Directorate of the Turkish Historical Society. Prior to fieldwork, investigations began with a thorough examination of previously published reports on the region. Since Van province is a particularly well-investigated area of the Urartian Kingdom, more time was dedicated to areas that are slightly off track from the better investigated royal centers within this region. During the survey, inquiries with local inhabitants also aided identification of archaeological sites. UTM coordinates of archaeological sites and epigraphic finds were recorded with a hand-held GPS. Sites were marked on the 1:25.000 scale topographic map sheets for the surveyed area, as reported in Table 1. Additionally, ceramic sherds were collected from the surface for chronological assessment of sites visited during the survey. Investigated sites were typologically categorized as fortress, mound or rock-cut tomb, based on their topographic layout, location, architectural remains, and ceramic finds. Sites were mapped to scale, technical illustrations were completed, and sites and features were thoroughly documented by photography.

\section{Geographical Characteristics and the Boundaries of the Research Area}

Tuşba and Muradiye districts of Van province are located in the northern part of Van Plain, which constitutes the investigation area of our survey project (Fig. 1). This northern zone is where the northern, western, and eastern routes of the Urartian road network are located. In Tuşba district, the routes go through Tımar Plateau to reach out north, since access to the region is topographically restricted by Lake Van in the west and by Lake Erçek in the east. The most prominent mountains along this route are Ereni/Ireni

\footnotetext{
${ }^{8}$ This route runs parallel to the East-West-oriented Murat River valley, which is a natural corridor that connects settlement basins. However, it is rather unlikely that the Urartian state would have invested in the construction of a long and partially stone-paved road along this natural route that lies far away from the core region of the kingdom.
} 
(elevation from sea: $2250 \mathrm{~m}$ ), Poğanis (2300 m), Eğlence (Hanege) (2450 m) and Isabey ( $2837 \mathrm{~m})$, which constitute the most marked elevations in the topography of the region between the Karasu Stream and the eastern coast of Lake Van. All of these mountains are located north of Karasu, except for Mt. Poğanis to the south. Karasu Stream, a major part of which runs through Tuşba district, and Lake Erçek, which is an alkaline lake like Lake Van, are the most important freshwater resources of the region. Karasu Stream ${ }^{9}$ is formed by the confluence of perennial streams that originate from the mountainous zone along the modern Turkish-Iranian border. ${ }^{10}$ Sarımemet Dam, constructed on the 148 -km-long Karasu Stream, is an important water reservoir for the region. The east-west-flowing Karasu Stream runs through narrow gorges across the mountains where it originates and through the mountainous zone north of Lake Erçek. Then, the river continues to flow across a relatively wide and flat plateau west of Lake Erçek before merging into Lake Van. Bendimahi Stream originating from the mountainous zone in Çaldıran, north of Muradiye district, flows southwards and merges into Lake Van at the northwestern tip of the lake around Karahan neighborhood.

\section{Road Routes Around Tuşpa}

The geographical distribution of Urartian Period centers in Van region demonstrates that the territorial expansion through military means followed two major routes to the north and the northeast of Van Plain. These two main transportation routes are the Capital North Road Main Route and the East Road Route (Fig. 1). The first section of the Main Northern Route is the road between capital city Tuşba and Körzüt Kalesi in Muradiye Plain. In addition to these two main routes, we identified other alternative routes, which had developed over time throughout the history of the kingdom. One of these alternative routes is the North Coast Route, which runs along the northern coast of Lake Van. The second route follows Karasu Valley north towards Muradiye and can be identified as the Karasu Valley Route. These auxiliary routes meet in Muradiye Plain, which lies nearby the northeastern tip of Lake Van. Muradiye Plain is located at a strategic point where the transportation road network diverges west, north, and east. The third auxiliary route identified by our surveys is the East Road Route, which departs from Van Plain, runs parallel to the southeastern coast of Lake Erçek until Özalp district, and continues into Salmas Plain via Kotur Valley providing access to Northwestern Iran.

\section{North Road Main Route from Van Plain to Muradiye Plain}

The main transportation route of the Urartian Kingdom that runs along the north coast of Lake Van before diverging west (Muradiye-Erciş-Patnos-Malazgirt-BulanıkMurat River Valley) and north (Muradiye-Çaldıran -Doğu Beyazıt-Iğdır Plain-Erivan) was utilized especially for military campaigns. The first section of this route that lies between Van Plain and Muradiye Plain is constituted by the Tuşpa-Körzüt route. This route departs from the capital city at Tuşpa; it follows the modern Van-Ağrı highway that

\footnotetext{
${ }^{9}$ Saraçoğlu 1989, p. 460.

${ }^{10}$ Çiftçi and et alii 2008, 54/Tab. 7.
} 


\section{Bilcan GÖKCE - Rlfat KUVANÇ- Bülent GENÇ}

passes nearby Kalecik Fortress and turns north after crossing Karasu Stream. The route runs parallel to the highway until Tabanlı neighborhood, where it turns east. Following a gently sloped valley northwest, the route then reaches Pirgarip neighborhood and continues towards Gedikbulak (Canik) neighborhood through small intermontane valleys. After Gedikbulak, the route follows the northeastern valley and crosses by Aliler Fortress, west of which a structure dating to the Urartian King Minua's reign is found. Then, the route follows the lake coast through Ermişler (Derebelek) neighborhood and reaches the Panz Plateau, where it runs parallel to the modern highway and crosses via Çakırbey pass into Ovapınar (Şivekar) neighborhood at the southwestern tip of Muradiye Plain. Thus, having entered the strategic zone of Muradiye Plain, the route culminates at Körzüt Fortress, which is the most prominent royal construction project in the plain.

Kalecik Fortress, located about $6 \mathrm{~km}$ north of Van province center ${ }^{11}$, is the first site situated along the initial section of the Urartian Capital North Road Main Route. Our investigations at this fortress site documented characteristic features of Urartian Period sites, including the masonry technique of fortification walls (particularly observable in the east), fortification wall foundation terraces, a stepped cistern, and typical Urartian ceramics collected from the surface (Fig. 2). This fortress is built on top of a rather small limestone outcrop with limited level ground suitable for construction. The construction of the fortress can be attributed to the Urartian King Ishpuini, based on a spolia block with a cuneiform inscription found inside the Armenian church at the site. ${ }^{12}$ This fortress was one of the military structures built during the early formative period of the kingdom to bolster the defenses of the royal core. The small size of this fortress suggests that it probably served as a watchtower. Routes that pass east and west of Kalecik Fortress converge into one main route further north, which runs parallel to the modern highway. The route goes across Yeşilköy Plateau and reaches Karasu (Ablanganis) Stream, which runs from east to west towards Lake Van. Just after crossing the river, the route diverges into a northern and an eastern route.

Another prominent structure along the first section of the Main Northern Route from Van to Muradiye is Aliler Fortress. This fortress lies between Karaağaç and Tutumlu neighborhoods about $54 \mathrm{~km}$ north of Van province center. It is built on top of a rocky outcrop located about $1.5 \mathrm{~km}$ east of the lake (Fig. 3). The most prominent architectural remains at the site are the fortification wall foundations on the southern slope of the rocky outcrop. Architectural foundations of a large complex, where a column base inscribed with the name of "Minua" was discovered, are located at the southwestern foothills of the rocky outcrop. A necropolis lies on the western and northwestern skirts of the hill, where most of the graves have been robbed and disturbed by illicit excavations. ${ }^{13}$ An auxiliary route to Aliler Fortress follows the small valley of Koluz Stream that runs between Timar and Karaağaç neighborhoods (Fig. 3/d). A necropolis and a hilltop fortress were discovered in the highland zone of Mount Eğlence (Hanege) located about $3 \mathrm{~km}$ northeast of Pirgarip neighborhood (Fig. 4). Wall remains are visible on two sides of this settlement that is built

\footnotetext{
${ }^{11}$ Burney 1957, p. 45; Korfmann 1977, p. 200.

12 Sayce 1882, pp. 454-455; CTU I, no. A2-1.

${ }^{13}$ Sevin 2003, pp. 373-376; Belli 2004.
} 
on top of a rocky outcrop. The rocky outcrop is located at a strategic spot with a commanding view of Lake Van and Lake Erçek. The necropolis associated with the fortress lies on the southern slope of the rocky hill and features cromlech and chamber tombs. After departing from this settlement area within the boundaries of Pirgarip neighborhood, the route passes west of Derebey Village and follows the valley of Koluz Stream; and crossing through the eastern slope of Aliler Fortress, the route reaches the coast of Lake Van.

Another important center by the eastern coast of Lake Van is Panz Fortress, which has been documented in surveys prior to our research. ${ }^{14}$ We revisited this Early Iron Age fortress to conduct further investigations at the site. The fortress is constructed abiding by the northeast-southwest orientation of the natural topography of the hill. The structure has a rectangular layout and its 3.30-m-wide walls are constructed from roughly dressed andesite blocks (Fig. 5/a-c). Although the fortress was built in earlier periods, it was most evidently used during the Urartian Period as an important station along the northern route. After this fortress site, the Urartian Main Northern Route passes through Ovapinar and reaches Körzüt Fortress, which can be regarded as the most ambitious investment of the Urartu in fortifying its military defenses in Muradiye Plain. Also, a rock-cut tomb with a single chamber is found within the boundaries of Ermişler Village that is located between Panz Fortress and Aliler Fortress.

Passing through Karahan neighborhood at the northwestern tip of Lake Van, the Urartian North Road Main Route continues west into Erciş Plain. ${ }^{15}$ The most prominent site along this road section where we carried out investigations is Keçikıran (Demecımo) Fortress. ${ }^{16}$ This fortress is built on top of a rocky outcrop, located just north of VanErciş-Ağrı highway, about $1.5 \mathrm{~km}$ west of Keçikıran neighborhood, which lies approximately $12 \mathrm{~km}$ west of Muradiye district center (Fig. 6/a-c). Fortification walls are observable on the western slope of the rocky outcrop on top of which a rectangular structure measuring $63 \times 42 \mathrm{~m}$ is located. At the highest point of the rocky hill, the foundations of another building with well-dressed blocks and regular masonry can be identified as a temple. The characteristics of its architectural remains and its strategic location indicate that this fortress site was a royal construction project.

\section{Northern Karasu Valley Route}

As mentioned above, the northern route departing from the capital city Tušpa diverges into two main routes at the point where it reaches Karasu Stream. The first site we investigated in Karasu Valley is Dibekdüzü Mound. The mound is located within the plain that lies $4 \mathrm{~km}$ southeast of Alaköy Village, which is located $3 \mathrm{~km}$ west of the modern Van-Ağrı highway, about $20 \mathrm{~km}$ north of Van province center. Previous investigations at the mound have documented a long settlement history since the Late Chalcolithic. ${ }^{17} \mathrm{~A}$

\footnotetext{
${ }^{14}$ Belli and Konyar 2003, pp. 10-14.

${ }^{15}$ Investigation of the western extension of the Northern Route in Erciş district was among the planned objectives of the 2020 season. However, due to the Covid-19 pandemic, this investigation is postponed until the next season.

16 Sevin 2006.

${ }^{17}$ Abay 2009.
} 


\section{Bilcan GÖKCE - Rlfat KUVANÇ- Bülent GENÇ}

small number of Iron Age ceramic sherds were found inside illicitly excavated pits on top of the mound during our investigations at the site. Further east along the Karasu Stream, Gülsünler Mound is the most prominent archaeological site in the region that lies west of Lake Erçek. The mound is orientated parallel to Karasu Stream, situated only $1 \mathrm{~km}$ east of Gülsünler (Şıxara) neighborhood that lies on the southern bank of the river (Fig. 7). A well-established Middle Iron Age / Urartian Period settlement phase has been documented at the mound by previous investigations, in addition to other settlement periods. ${ }^{18}$ The most notable diagnostic assemblages from the pre-Urartian levels of the site are the Kura-Araxes wares of the Early Bronze Age, which indicate that the site was a preferred location for settlement since prehistoric periods. Our investigations at the site documented many sherds of Urartian brick-red ware (Fig. 7/b) and Urartian red burnished ware (Fig. 7/c), encountered on the surface and inside illicitly dug pits. Continuing along the river from this mound, one reaches Kasımoğlu (Günents) neighborhood that lies on the southern bank of Karasu, just like Gülsünler. Kasımoğlu is the locality where an inscribed stela recounting a military campaign dating to the co-reign of Urartian King Ishpuini and his son Minua (820-810 BC) was discovered. The stela chronicles the military campaigns of both kings into the northern highlands along Ağr1-Kağızman-Kars route inhabited by Luša, Katarza and Uiteruhi tribes. ${ }^{19}$ This stela that is on display today in Van Archaeological Museum was discovered in a church in this neighborhood, although it was certainly brought to this spot from a different location. Nevertheless, its findspot along the northern route corroborates the military ventures it recounts.

After departing from Kasımoğlu neighborhood, the road continues east following Karasu Stream as it goes through the Adıgüzel, Satıbey and Koçköy neighborhoods along the riverbank. After Koçköy, the topography of the river valley changes as Karasu cuts through a deep gorge. Siyahtaş Fortress is located in the mid-section of this gorge, Karasu Canyon, which continues northeast. The fortress is situated on top of an andesite hill, located $1 \mathrm{~km}$ northwest of Değirmenözü neighborhood. The remains of a structure with 1 -m-wide walls, measuring about $2.5-3.0 \mathrm{~m}$ on each side is documented at the highest point of this hill that has a commanding view of the entire Karasu Canyon. This structure can be identified as a watchtower based on its size and location.

The section of the route that departs from Değirmenözü continues northeast and reaches Sarımemet Plain within the Karasu Valley. The two sites investigated along this section of the route are Kuç and Harabe Fortresses located within the boundaries of Kuşçu neighborhood of Muradiye district. Kuç Fortress is located west Kuş̧u neighborhood, on top of a high rocky outcrop that overlooks the Karasu Canyon (Fig. 8/a-c). The site covers an area that measures $29.44 \mathrm{~m}$ along the east-west axis and $37.90 \mathrm{~m}$ along the north-south axis. The fortress is surrounded by a fortification wall. The western sector of the fortification wall is $2 \mathrm{~m}$ wide and features four bastions. The bastion located at the southwestern corner of the site is constructed out of bedrock. The first bastion measures $3.64 \times 3.76 \times 2.73 \mathrm{~m}$, the second $3.30 \times 2.90 \times 2.80 \mathrm{~m}$, the third $2.90 \times 3.5 \times 2.70 \mathrm{~m}$, and the fourth $2.5 \times 3.5 \times 2.10 \mathrm{~m}$. The distance between the first two bastions is $8.40 \mathrm{~m}$; the

\footnotetext{
18 Özfirat 2012, pp. 155 ff; 2015, p. 3.

${ }^{19}$ CTU I, no. A3-5.
} 
distance between the second and the third is $4.00 \mathrm{~m}$; and the distance between the last two bastions is $9 \mathrm{~m}$. A small number of Iron Age (Urartian) ceramic sherds were found at the fortress and in the vicinity. The second site along this route section in Muradiye district, Harabe Fortress, is located on a natural rocky outcrop that lies east of Sürüyolu (Pirsolan) neighborhood within Sarımemet Plain. This site was documented in previous surveys. ${ }^{20}$ Foundations of fortification walls are observable in various sectors of the site. Particularly notable are the foundation terraces cut into the bedrock on the southern slope, where six courses of the wall body are preserved. This fortress is an important station controlling both the northern and the eastern routes.

In Kuşçu neighborhood, which is located at the western end of Sarımemet Plain, Karasu Valley Route turns north, thus diverging from Karasu Stream valley. At this point, the route follows the eastern foothills of Mount Hesentap towards north through Erişen (Dambat), Esenkoç (Kebabık), and Otlakbaşı, and reaches Avgarıs Valley, which provides access to Muradiye Plain through Topuzarpa neighborhood. Avgaris Fortress, discovered during our investigations, is located on top of a rocky outcrop at the entrance to this valley. The location of this site has a commanding view of the valley; however, its architectural remains are not well-preserved. Also located along the northbound route from Sarımemet Plain, at the point where the route turns west through the valley lying west of Otlakbaşı neighborhood, another fortress was identified by our team (Fig. 9/a). Known as Kelle by local inhabitants, this fortress is a fortified site that features a bastion on the northern sector of the fortifications. However, this bastion is very poorly preserved, and the walls have collapsed. The wall body of the bastion consists of three courses, preserved to a height of $90 \mathrm{~cm}$. The 1.50-m-long bastion wall features a $60 \mathrm{~cm}$-wide projection. Many ceramic sherds were found on the surface across the northwestern slope, which suggests that this area was probably used as a necropolis. Belli states that this section of the Urartian road goes through the Akbulak (Aprak) - Uluşar (Korsot) route, which crosses a very rough terrain. ${ }^{21}$ However, according to our observations, the road through Esenkoç (Kebabık), Otlakbaşı (Mezre), and Topuzarpa (Anguzek) seems like a more convenient route for accessing Muradiye Plain. Not incidentally, this route leads to the clearing in front of Körzüt Fortress that lies just across from Topuzarpa neighborhood. An inscribed stela dating to the reign of Urartian King Minua $(810-785 / 80 \mathrm{BC})$ was found in the late- $19^{\text {th }}$ century in the vicinity of Topuzarpa, which corroborates that the Urartian route indeed followed this route for reaching Muradiye Plain. This stela had then been lost after having been initially documented about a century ago. During our survey at the site, we were able to re-discover this stela and transport it to Van Archaeological Museum.

\section{Sites Along the Northeastern Coast of Lake Van}

In addition to the Main Northern Route and Karasu Valley Route, detailed above, surveys were carried out along the Coastal Route that departs from Van Fortress and follows the coast of Lake Van towards the north. In order to identify archeological sites

\footnotetext{
20 Özfirat 2007, p. 145.

${ }^{21}$ Belli 1977, pp. 105 ff.
} 


\section{Bilcan GÖKCE - Rlfat KUVANÇ- Bülent GENÇ}

along this route in the northwestern sector of Van Plain, investigations were carried out first in Bardakçı (Zeve) neighborhood situated on the lake shore, and then, Topaktaş (Mermit) neighborhood further inland from the coast was visited (Fig. 10). Here, various structures and features were documented, such as the Kalecik Fortress located on top of a limestone outcrop and featuring a rock-carved staircase that most probably belongs to a watchtower, a cistern, and two T-shaped niches carved into the bedrock. This rocky outcrop has a commanding view of both the coastline and the route towards Timar (Fig. 10/a-b). Departing from Topaktaş, our survey route passed through Çitören (Anmeşat) neighborhood and followed the coastline. A rock-cut, single-chamber tomb was discovered by our team on the westernmost hilltop of conglomerate rolling hills that extend along Çarpanak peninsula, northwest of Çitören neighborhood (Fig. 11/a). After Cape Çarpanak, the coastal route toward north reaches a flat plateau where Mollakasım neighborhood is located. However, the next section of the route crosses a rugged terrain. After departing Mollakasım, our survey itinerary followed the route that goes through the following neighborhoods along the coast: Ağartı (Ayanis), Özyurt (Panzis), Dağönü (İreni), Yeşilsu (Amok), Halkalı (Hicşk), Yaylıyaka (Adır), and Kumluca (Norşin). However, the steep and uneven topography of this road renders it very unlikely for it to have been a transportation route for the Urartu. In this regard, how transportation and access to the Urartian Fortress at Ayanis, located on top of a natural hill just by the lake in Ağartı neighborhood, is an intriguing question. After crossing Timar Plateau, the road to Ayanis Fortress probably went through the valley and the small hill that lie south of Mount Ireni and north of Alaköy neighborhood. Indeed, this short route segment that is only $4 \mathrm{~km}$ long, was appropriately defended by Alaköy/Garibintepe Fortress that is located $2 \mathrm{~km}$ north of Alaköy. Fragments of a basalt lion statue, dating to the Urartian Period were found at the Urartian Fortress of Garibintepe. ${ }^{22}$

One of the most prominent peaks along the east coast of Lake Van is the rocky outcrop where Amik Fortress is located. The architectural remains on top of this rocky hill that lies $14 \mathrm{~km}$ northeast of Ayanis Fortress date to the Medieval Period. Although no diagnostic remains datable to the Urartian Period were encountered at this hilltop, a Tshaped niche similar to the ones found at Kalecik and Topaktaş was discovered in the vicinity (Fig. 1/b-c).

\section{Eastern Route}

Inscriptions dating to the reign of Ishpuini, the co-reign of Ishpuini and Minua, and the reign of Minua (late $9^{\text {th }}$ - early $8^{\text {th }}$ centuries BC) show that the Urartian state was organizing military campaigns to Northwestern Iran, Nakhchivan, and NagornoKarabagh, since the formative period of the kingdom. Anzaf Fortresses in Tuşpa district and the niched inscription at Yeşilalıç in Özalp district are the most illustrative pieces of evidence, which demonstrate that the Urartian military utilized the route through Özalp Kotur for their eastern campaigns. Besides its strategic importance for the Urartian military campaigns into Northwestern Iran, this region was also an important settlement

\footnotetext{
22 Derin and Sağlamtimur 1998, pp. 15-23.
} 
area for the kingdom. Many Urartian Period settlements have been discovered during investigations led by W. Kleiss since the 1960s in Northwestern Iran, which indicates that this region was one of the primary areas where the kingdom expanded. Our survey itinerary for this route departed from the capital city Tushpa and proceeded along the transportation routes within the boundaries of Tuşba district. The first military station on this route is at the fortress sites of Anzaf, which consist of a lower (Aşağı) and an upper (Yukarı) fortress, first discovered by Burney. Aşağı Anzaf Fortress is situated just next to the Van - Iran railway about $11 \mathrm{~km}$ northeast of Van Fortress, while Yukarı Anzaf Fortress is located about $900 \mathrm{~m}$ south of the lower fortress. Systematic excavations were conducted at Aşağı and Yukarı Anzaf Fortress sites for 16 years between 1991 and 2006. Investigations documented important architectural structures of these two fortresses that were built during the formative period of the Urartian Kingdom in the vicinity of the capital at Van Fortress (Tuşpa).

The north-south-oriented Aşağı Anzaf Fortress lies on top of a limestone outcrop with a relatively even terrain. The fortress has a rectangular layout, measuring $62 \times 98 \mathrm{~m}$. Aşağı Anzaf was built during Ishpuini's reign, and it was inhabited in later periods, as well, especially during the Medieval Period, when the site hosted a sizeable settlement. The most prominent architectural remains of the Urartian fortress are the still-standing fortification walls constructed from large limestone blocks. Yukarı Anzaf Fortress is much larger than the lower fortress and was built during Minua's reign, as can be surmised from building inscriptions. Important Urartian Period buildings were documented during excavations at the fortress citadel. These are Lower Town East Gate, magazines attached to the eastern fortification wall, northern and southern fortress gates, Great Tower, Haldi Temple, palace complex, and cooking and storage complexes. ${ }^{23}$

Anzaf Fortresses, which are two crucial military stations located on the Eastern Road Route, are part of a defensive system designed by the Urartian state to create a security chain around the capital city Tushpa. Departing from Anzaf, the route continues east passing by the south of Lake Erçek towards east of the lake. The route then goes through the valley following the modern Van-Özalp highway and reaches Özalp Plain. After crossing Özalp Plain, the route diverges into an eastern and a southern route, both of which reach Kotur Valley just east of the modern Turkish-Iranian border. At the eastern termination of this valley, lie the two major settlement plains, Salmas and Hoy, northwest of Lake Urmia.

\footnotetext{
${ }^{23}$ Our most striking observation at these two significant royal centers in the core region of the Urartian Kingdom is the poor state of preservation of archaeological remains and deposits. Having been abandoned exposed to the impact of natural elements after the termination of excavations in 2008, archaeological remains at both sites have been severely damaged. Particularly at Yukar1 Anzaf, mudbrick walls of the palatial complex have disintegrated with the impact of rain and snow and large portions of the walls have collapsed as a whole. Yukarı Anzaf Fortress is one of the few Urartian fortress sites where the mudbrick superstructure of buildings has been preserved and documented. Given the current state of the site vis-à-vis its significance, re-initiation of excavations geared towards conservation and restoration at the site seems imperative for the preservation of extant excavated evidence.
} 


\section{Bilcan GÖKCE - Rlfat KUVANÇ- Bülent GENÇ}

\section{Conclusions}

In 2017-2018, our investigations in Tuşba and Muradiye districts centered around Van Fortress and taking the capital city as a point of departure, surveys documented the northern and eastern routes of the Urartian transportation network in this territory. Field surveys identified two northern routes that depart from Van Fortress and continue abiding by topographical features: North Road Main Route and East Road Route. In addition to these major routes, an auxiliary Coastal Route along Lake Van and another alternative route through Karasu Valley were also defined. In conclusion, the layout of these routes demonstrates that Muradiye Plain, where major northern routes of the Urartian transportation network converge, was a key strategic region for the Urartu.

Apart from investigations carried out at Urartian sites documented in previous surveys, four previously unknown fortresses and one previously unknown rock grave were identified by our survey project in Muradiye and Tuşba districts. General characteristics of the fortresses at Siyahtaş, Kuç, Avgaris, and Kelle imply that these were small-scale military constructions built for defending a restricted local zone, rather than being royal construction projects of grand proportions. Especially some of the fortresses on the northern route of the Urartian Kingdom, such as fortresses at Kalecik and Aliler, must have been military watchtowers and checkpoints controlling the routes that reach Tuşpa through Van Fortress - Körzüt route. At three sites, namely Topaktaş, Kalecik, and Amik Fortress, we encountered T-shaped niches carved into the rock façades. The most exquisitely carved examples of these T-shaped niches are known from the vicinity of the capital at Van. However, the function of these niches is not clear. The auxiliary route that runs parallel to the eastern coast of Lake Van is not suitable to be a royal or military route. In fact, apart from Ayanis Fortress, there are no notable Urartian sites along this route. Rather than the coastal route, access to Ayanis Fortress (built by Rusa, son of Argishti) must have been maintained via an auxiliary road through Alaköy that merges into the Main North Route towards Van and Timar Plains. One of the significant outcomes of our survey project was the discovery of Urartian inscriptions found within the boundaries of the research area. Especially many inscriptions discovered in Karahan neighborhood of Muradiye province reveal important observations about Urartian hegemony in this region.

A general conclusion that arises from our investigations is that, since the foundation of their kingdom, Urartu opted for a settlement system that relied on the administrative control of fertile agricultural land especially in Lake Van Basin, which they established by means of royal fortresses and military stations. Transportation routes that provided access to the capital and the royal core, on the other hand, were defended by small watchtowers and checkpoints built at strategic spots, often with a commanding view of the surrounding landscape. 


\section{BIBLIOGRAPHY}

Abay 2009

Barnett 1982

Belli 1977

Belli 2000

Belli 2004

Belli and Konyar 2003

Burney 1957

CTU I

CTU IV

Çiftçi and et alii. 2008

Dan 2018
Eşref Abay, "Dibekdüzü. Van/Ayanis Kalesi Yakınında Bir Höyük Yerleşimi”. Altan Çilingiroğlu'na Armăgan. Yukart Denizin Kıyısında Urartu Krallığı'na Adanmış Bir Hayat/ Studies in Honour of Altan Çilingiroğlu A Life Dedicated to Urartu on the Shores of the Upper Sea. (eds.) H. Sağlamtimur et al. İstanbul, Arkeoloji ve Sanat Yayınları: pp. 67-85

R. D. Barnett, "Urartu". The Cambridge Ancient History, Volume 3/1: The Prehistory of the Balkans, the Middle East and the Aegean World, Tenth to Eighth Centuries BC. (eds.) J. Boardman, I. E. S. Edwards, N. G. L. Hammond and E. Sollberger. Cambridge University Press: pp. 314-371.

O. Belli, Urartu Bölgesi Yol Şebekesi. PhD dissertation, İstanbul Üniversitesi, Sosyal Bilimler Enstitüsü, İstanbul.

O. Belli, "Doğu Anadolu'da Urartu Yol Şebekesinin Araştırılması". Türkiye Arkeolojisi ve İstanbul Üniversitesi (1932-1999). (ed.) O. Belli. Ankara, İstanbul Üniversitesi: pp. 409-414.

O. Belli, "An Early Iron Age and Urartian Fortress in The Van Region: Aliler", Studi Micenei ed Egeo-Anatolici 46-1, pp. 5-14.

O. Belli and E. Konyar, Doğu Anadolu Bölgesi'nde Erken Demir Çă̆ Kale ve Nekropolleri, İstanbul, Arkeoloji ve Sanat Yayınlar1.

C. A. Burney, "Urartian Fortresses and Towns in Van Region", Anatolian Studies 7, pp. 37-53.

M. Salvini, Corpus Dei Testi Urartei, Vol. I-III, (CTU I-III), Istituto di Studi Civilta Dell'e Egeo Del Vicino Oriente, Documenta Asiana, 2008, Roma

M. Salvini, Corpus Dei Testi Urartei, Vol. IV: Iscrizioni Su Bronzi, Argilla E Altri Supporti Nuove Iscrizioni, Editions De Boccard, 2016.

Y. Çiftçi, M. A. Işık, T. Alkevli and Ç. Yeşilova, "Van Gölü Havzasının Çevre Jeolojisi / Environmental Geology of Lake Van Basin", Jeoloji Mühendisliği Dergisi 32/2, pp. 45-77

R. Dan, "Some Reflections on 'Urartian Roads and Urartian Road System/Urartu Yol Sistemi ve 'Urartu' Yolları Üzerine Bazı Düşünceler”. Eski Yakındoğu'da Ulaşım Üzerine Yazllar/Articles on Transportation in Ancient Near East. (eds.) B. Gökce and P. Pınarcık. İstanbul, Akademisyen Yayınevi: pp. 355-367.

Derin and Sağlamtimur 1998

Z. Derin and A. H. Sağlamtimur, "Alaköy Kalesi ve Kalede 


\section{Bilcan GÖKCE - Rıfat KUVANÇ- Bülent GENÇ}

Iş̧1k 2017

Korfmann 1977

Özfirat 2007

Özfirat 2012

Özfirat 2015

Salvini 2001

Saraçoğlu 1989

Sayce 1882

Sevin 1989

Sevin 2005

Sevin 2006

Zimansky 1985

Zimansky 2005
Bulunan Urartu Heykelleri”, Belleten LXII/233, pp. 15-23.

K. Işık, Urartu Yazılı Kaynaklarında Geçen Yer Adları ve Lokalizasyonlarl. $\mathrm{PhD}$ dissertation, Van Yüzüncü Y1l Universitesi Sosyal Bilimler Enstitüsü Protohistorya ve Önasya Arkeolojisi Anabilim Dalı.

M. Korfmann, "Die Ausgrabungen von Kirsopp und Silva Lake in den Jahren 1938 und 1939 am Burgfelsen von Van (Tušpa) und in Kalecik", Berytus XXV, pp. 173-200.

A. Özfirat, "Van, Ağrı, Iğdır İlleri Yüzey Araştırması, 2005", Araştırma Sonuçları Toplantısı 24/1, pp. 143-162.

A. Özfirat, "Van, Ağrı ve Iğdır İlleri Yüzey Araştırması, 2010", 29. Araştırma Sonuçları Toplantısı, pp. 155-173.

A. Özfirat, "Van Gölü Havzasında Yeni Araştırmalar", XVI. Türk Tarih Kongresi I, pp. 1-17.

M. Salvini, "Inscription on Clay". Ayanis I. Ten Years of Excavations at Rusahinili Eiduru-kai 1989-1998. (eds.) A. Çilingiroğlu and M. Salvini. Roma, pp. 279-319.

H. Saraçoğlu, Doğu Anadolu Bölgesi, MEB Öğretmen Kitapları Dizisi, İstanbul.

A.H. Sayce, "The Cuneiform Inscriptions of Van, Deciphered and Translated", The Journal of the Royal Asiatic Society of Great Britain and Ireland 14/4, pp. 377-732.

V. Sevin, "Urartular'a Ait Dünyanın En Eski Karayolu", Anadolu Araştırmaları XI, pp. 47-56.

V. Sevin, "Son Tunç/Erken Demir Çağı Van Bölgesi Kronolojisi. Kökeni Aranan Bir Devlet: Urartu”, Belleten 252, pp. 355-400.

V. Sevin, "Keçikıran: Van Bölgesinden Yarım Kalmış Bir Urartu Projesi”. Hayat Erkanal'a Armağan. Kültürlerin Yansımasi/ Studies in Honor of Hayat Erkanal. Cultural Reflections. (eds.) A. Öktü, E. Özgen et al., İstanbul, Homer Kitabevi: pp. 667-674.

P. E. Zimansky, Ecology and Empire: The Structure of the Urartian State, Chicago

P. E. Zimansky, "The cities of Rusa II and the end of Urartu". Anatolian Iron Ages 5: Proceedings of the Fifth Anatolian Iron Ages Colloquium held at Van, 6-10 August 2001. (eds.) A. Çilingiroğlu and G. Darbyshire. London, British Institute at Ankara: pp. 235-240. 


\begin{tabular}{|c|c|c|c|c|}
\hline Name & $\begin{array}{l}\text { Map Code } \\
(1: 25.000) \\
\end{array}$ & District & Location & $\begin{array}{c}\text { Settlement } \\
\text { Type }\end{array}$ \\
\hline $\begin{array}{l}\text { Van Kalesi } \\
\text { (Tushpa) }\end{array}$ & $\mathrm{K} 50 \mathrm{c} 4$ & İpekyolu & $\begin{array}{c}\text { approximately } 5 \mathrm{~km} \text { west of Van } \\
\text { province center }\end{array}$ & Fortress \\
\hline Kalecik & K50c4 & Tushba & $5 \mathrm{~km}$ north of Van Fortress & Fortress \\
\hline Aliler & K50b3 & Tushba & $\begin{array}{c}54 \mathrm{~km} \text { north of Van province center, } \\
\text { between Karaağaç and Tutumlu } \\
\text { neighborhoods }\end{array}$ & Fortress \\
\hline Panz & K51a1 & Tushba & $\begin{array}{l}51 \mathrm{~km} \text { north of Van province center, } \\
\text { in Çolpan neighborhood, } 1 \mathrm{~km} \text { west } \\
\text { of Van-Erciş Highway }\end{array}$ & Fortress \\
\hline Ovapınar & K51a2 & Muradiye & $\begin{array}{c}\text { close to the northwestern tip of Lake } \\
\text { Van, } 1.5 \mathrm{~km} \text { east of Van-Muradiye } \\
\text { highway }\end{array}$ & Mound \\
\hline Körzüt & K51a2 & Muradiye & $\begin{array}{c}\text { approximately } 9 \mathrm{~km} \text { south of } \\
\text { Muradiye district center, in Uluşar } \\
\text { (Korsot) neighborhood }\end{array}$ & Fortress \\
\hline Keçikıran & K51a1 & Muradiye & $\begin{array}{l}\text { on a natural rocky outcrop, } 1.5 \mathrm{~km} \\
\text { west of Keçikıran neighborhood, just } \\
\text { north of Van-Erciş-Ağrı highway }\end{array}$ & Fortress \\
\hline Dibekdüzü & K50d3 & Tushba & $\begin{array}{c}20 \mathrm{~km} \text { north of Van province center, } \\
3 \mathrm{~km} \text { west of Van-Ağrı highway, } 4 \\
\mathrm{~km} \text { southeast of Alaköy village }\end{array}$ & Mound \\
\hline Gülsünler & $\mathrm{K} 50 \mathrm{c} 2$ & Tushba & $\begin{array}{c}1 \mathrm{~km} \text { east of Gülsünler (Şıxara) } \\
\text { neighborhood }\end{array}$ & Mound \\
\hline Siyahtaş & K51a4 & Tushba & $\begin{array}{l}1 \mathrm{~km} \text { northwest of Değirmenözü } \\
\text { neighborhood }\end{array}$ & Fortress \\
\hline Kuç & K51a4 & Muradiye & $\begin{array}{l}\text { west of Kuşçu neighborhood, on top } \\
\text { of a high, natural hill overlooking the } \\
\text { Karasu Canyon }\end{array}$ & Fortress \\
\hline Harabe Kale & K51a3 & Muradiye & $\begin{array}{c}\text { on top of a natural hill east of } \\
\text { Sürüyolu (Pirsolan) neighborhood } \\
\end{array}$ & Fortress \\
\hline Avgaris & K51a3 & Muradiye & $\begin{array}{c}3 \mathrm{~km} \text { northwest of Otlakbaş1 } \\
\text { neighborhood }\end{array}$ & Fortress \\
\hline Kelle & K51a3 & Tushba & $\begin{array}{c}1 \mathrm{~km} \text { northwest of Kelle } \\
\text { neighborhood }\end{array}$ & Fortress \\
\hline $\begin{array}{l}\text { Topaktaş } \\
\text { (Mernit) }\end{array}$ & $\mathrm{K} 50 \mathrm{~d} 3$ & Tushba & $\begin{array}{c}\text { on a rocky outcrop just west of } \\
\text { Topaktaş neighborhood }\end{array}$ & Fortress \\
\hline $\begin{array}{l}\text { Çarpanak } \\
\text { Rock-cut } \\
\text { Tomb }\end{array}$ & K50d2 & Tushba & $\begin{array}{l}\text { northwest of Çitören neighborhood, } \\
\text { on the westernmost hilltop of } \\
\text { conglomerate rolling hills that extend } \\
\text { along Çarpanak peninsula }\end{array}$ & $\begin{array}{l}\text { Rock-cut } \\
\text { Tomb }\end{array}$ \\
\hline
\end{tabular}

Table 1. List of settlements investigated along surveyed routes. 


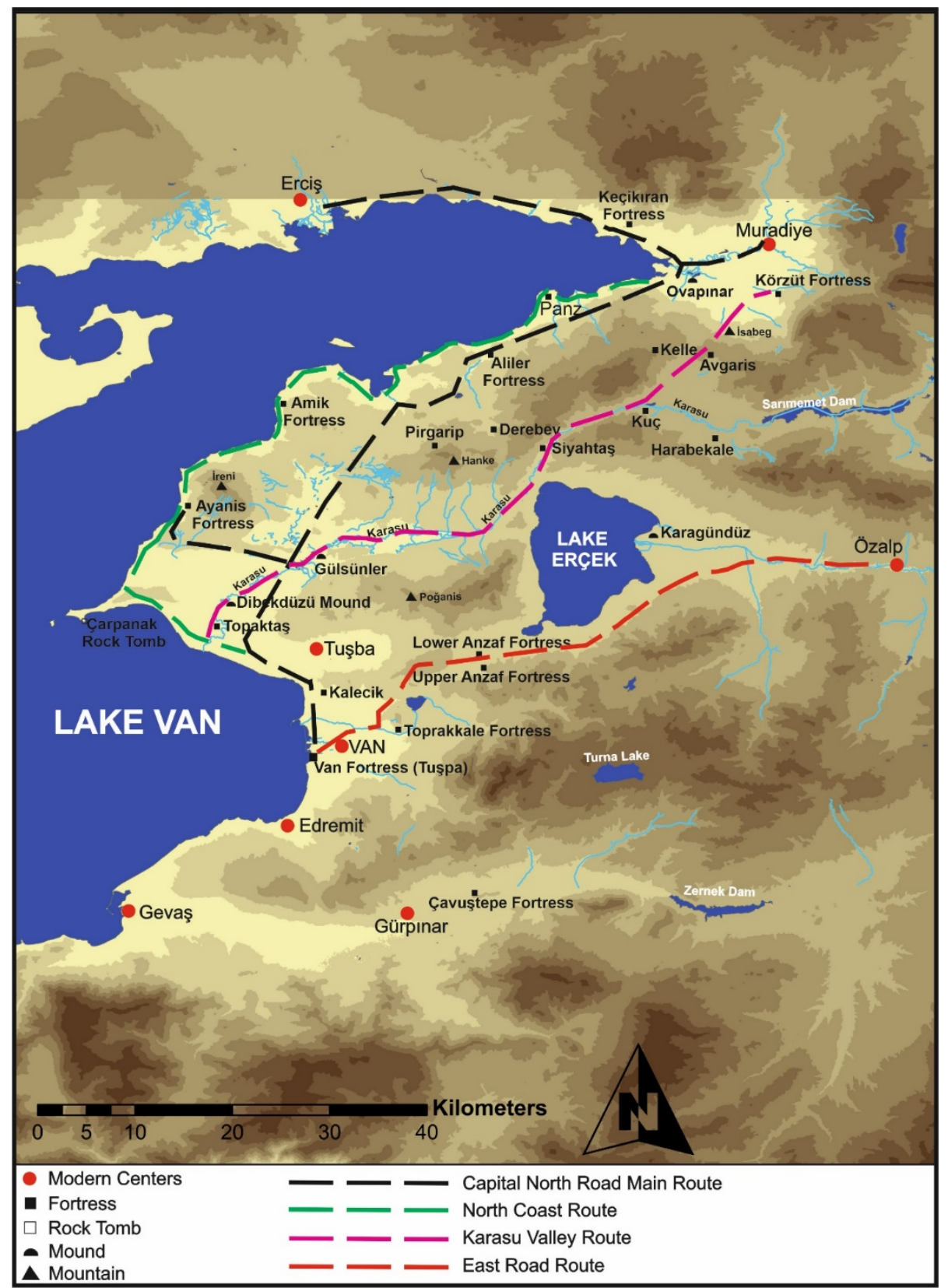

Fig. 1. Map of surveyed settlements located along transportation routes in Lake Van Basin. 

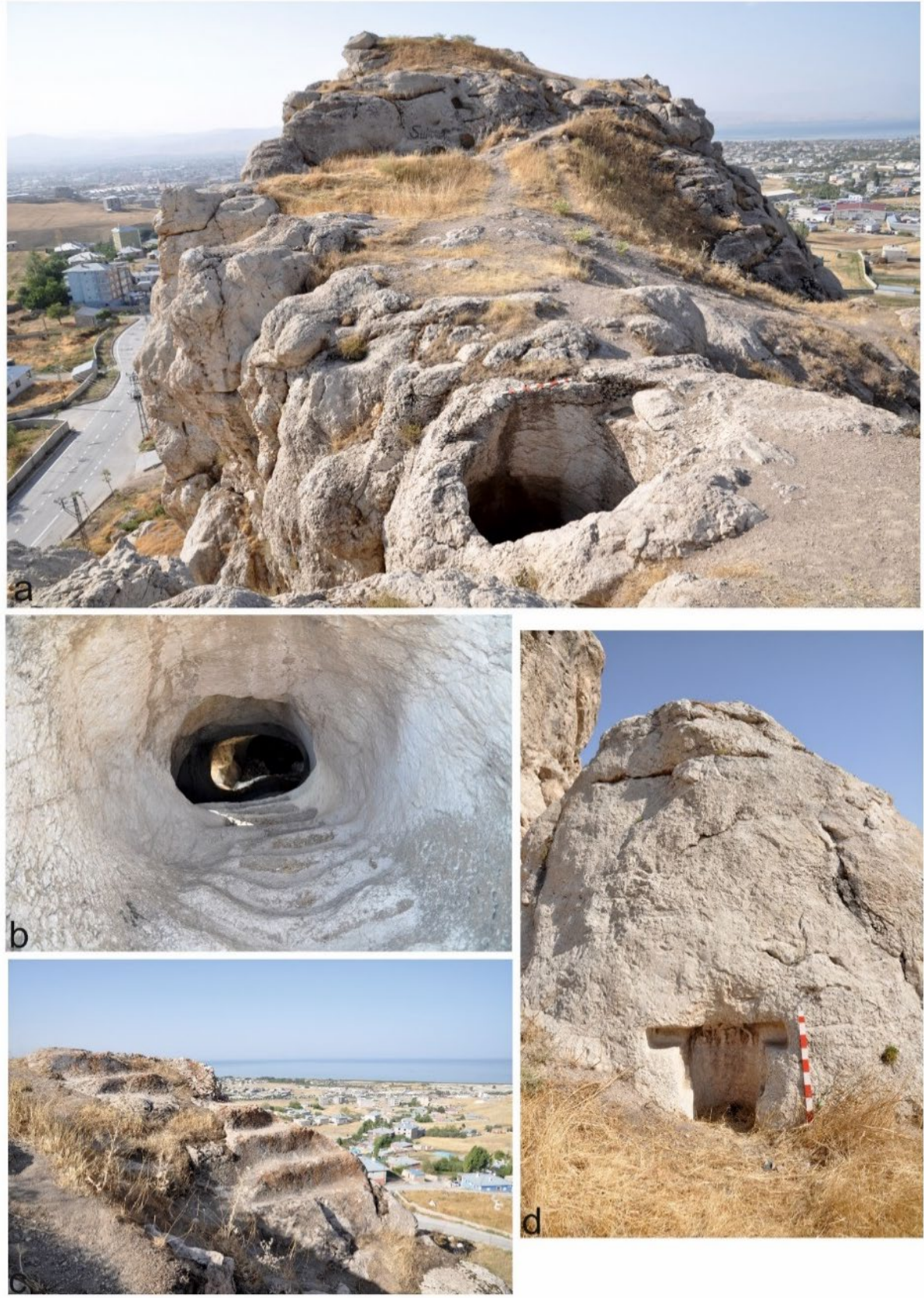

Fig. 2. Kalecik Fortress: (a) view from north, (b) cistern, (c) rock-cut staircase, (d) rockcut T-shaped niche, south of the fortress. 


\section{Bilcan GÖKCE - Rıfat KUVANÇ- Bülent GENÇ}
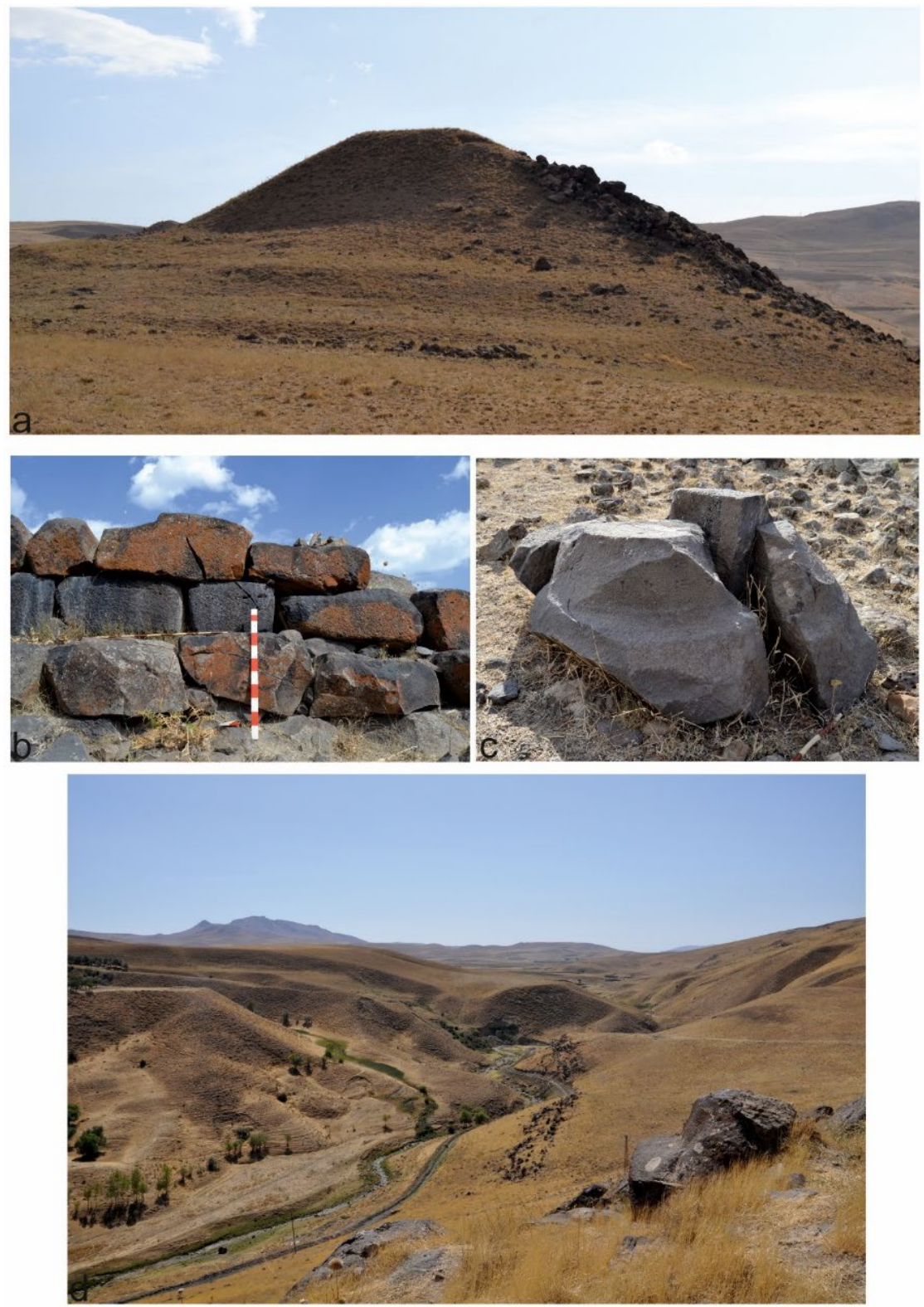

Fig. 3. Aliler Fortress: (a) view from west, (b) southern fortification walls, (c) fragmented column base bearing inscription "Minua", (d) the route that passes south of Aliler Fortress and reaches Derebey and Pirgarip. 

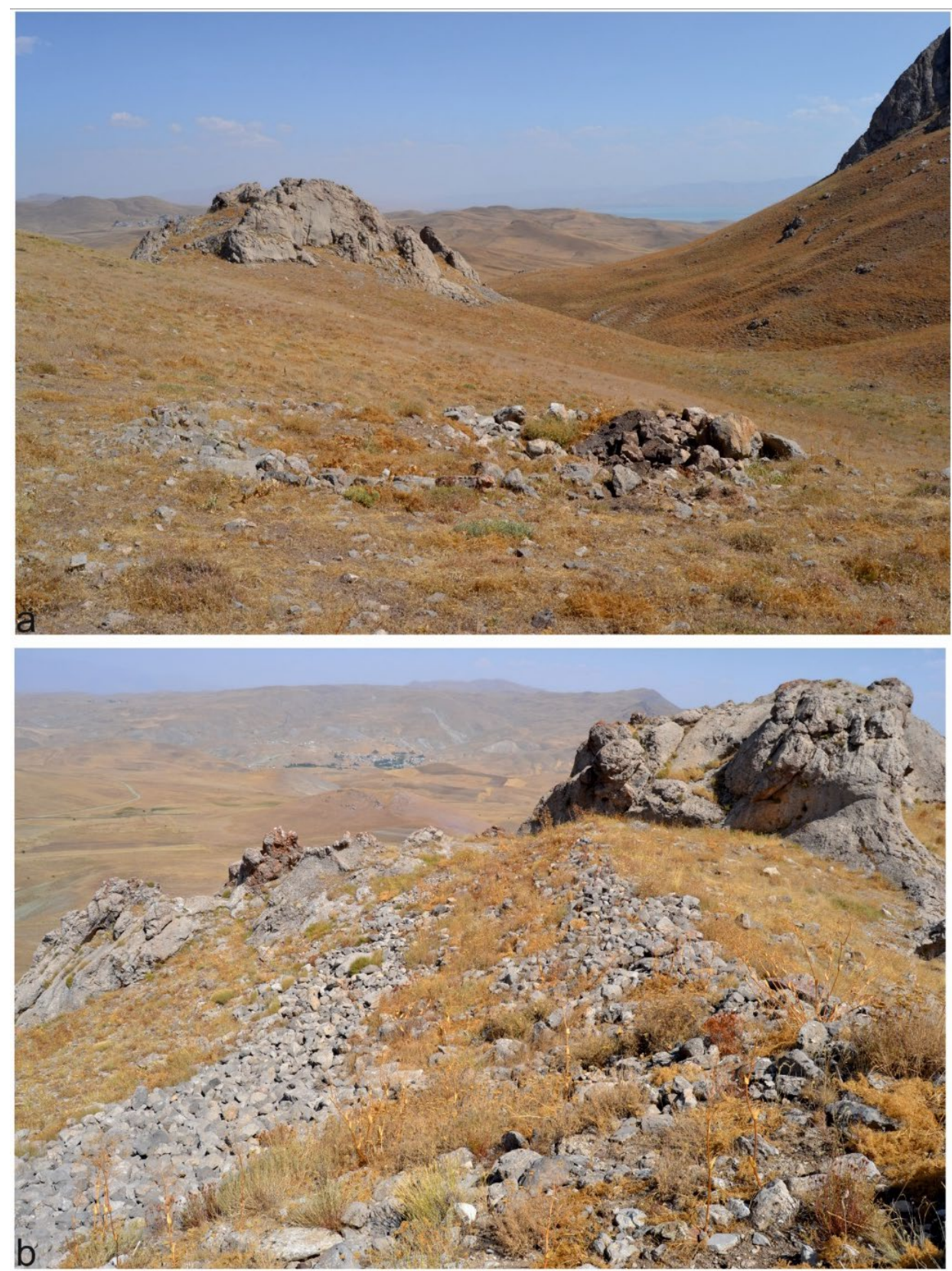

Fig. 4. Pirgarip Fortress: (a) view from west, (b) wall remains on the rocky outcrop 


\section{Bilcan GÖKCE - Rıfat KUVANÇ- Bülent GENÇ}
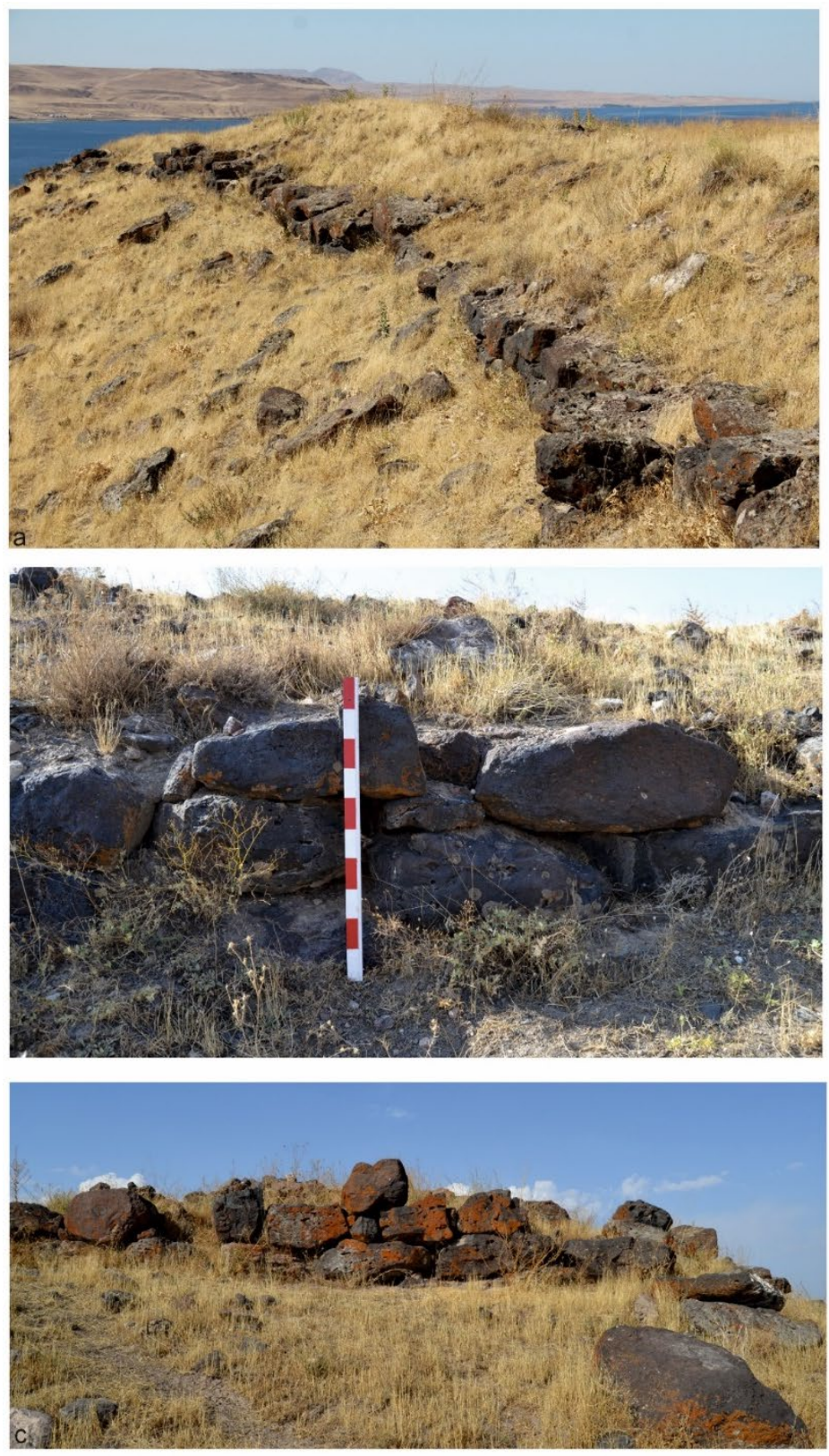

Fig. 5. Panz Fortress: (a) southeastern fortification walls, (b-c) detailed view of fortification walls, showing masonry and construction technique. 

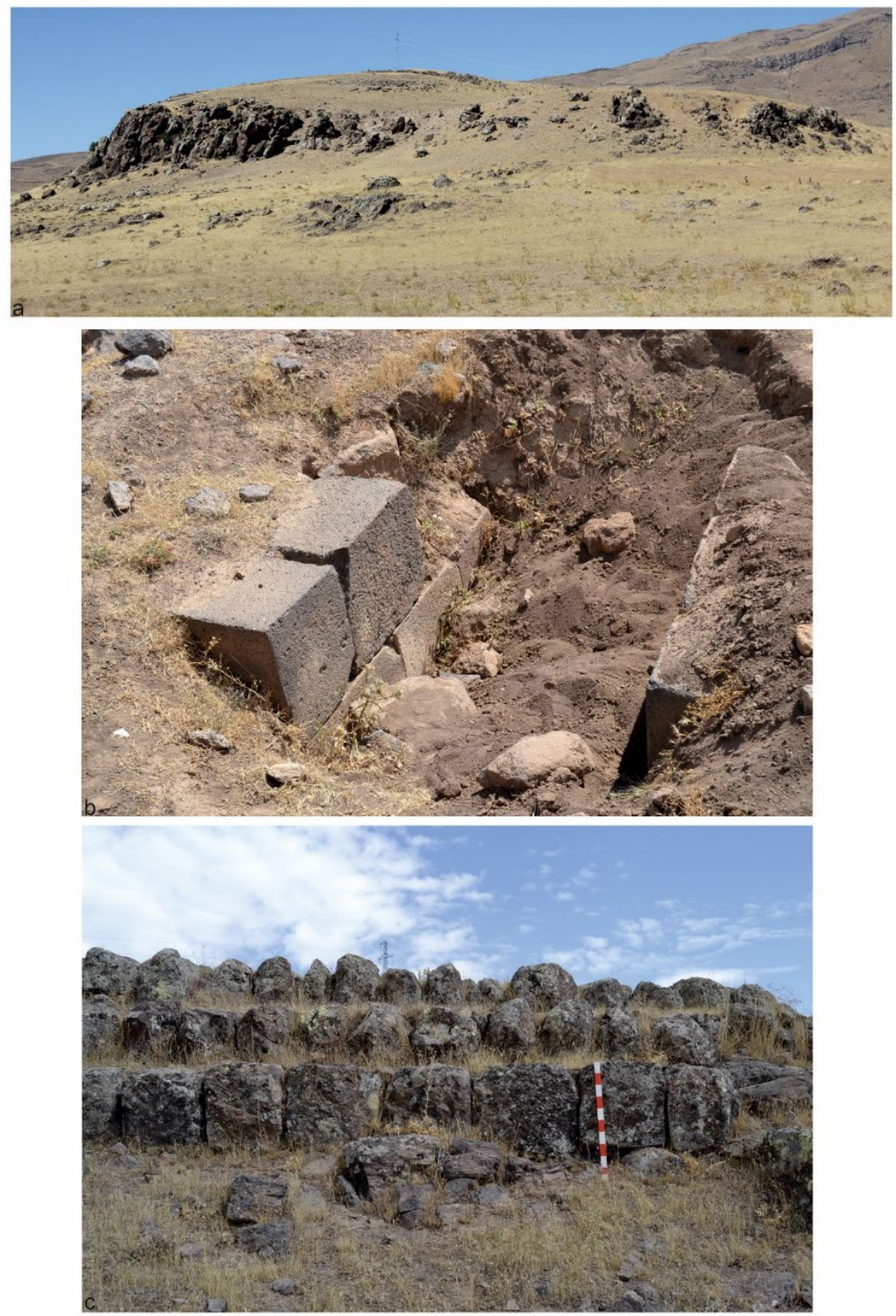

Fig. 6. Keçikıran Fortress: (a) view from south, (b) ashlar blocks in a wall segment, which probably belongs to a temple, (c) western fortification wall, construction technique. 


\section{Bilcan GÖKCE - Rıfat KUVANÇ- Bülent GENÇ}
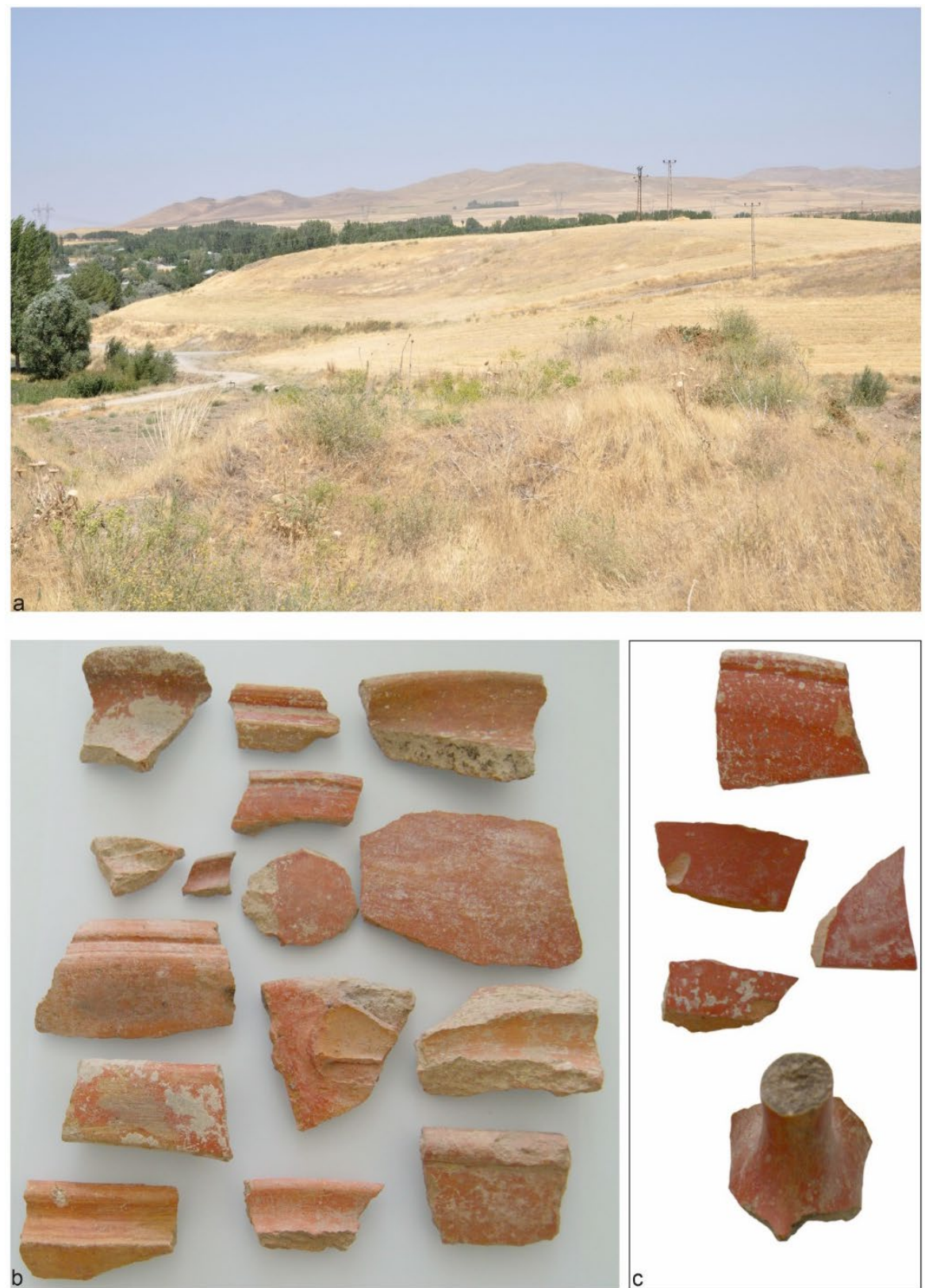

Fig. 7. Gülsünler Mound: (a) view from west, (b) examples of brick-red ware from the site, (c) examples of red glossy Bianili ware. 

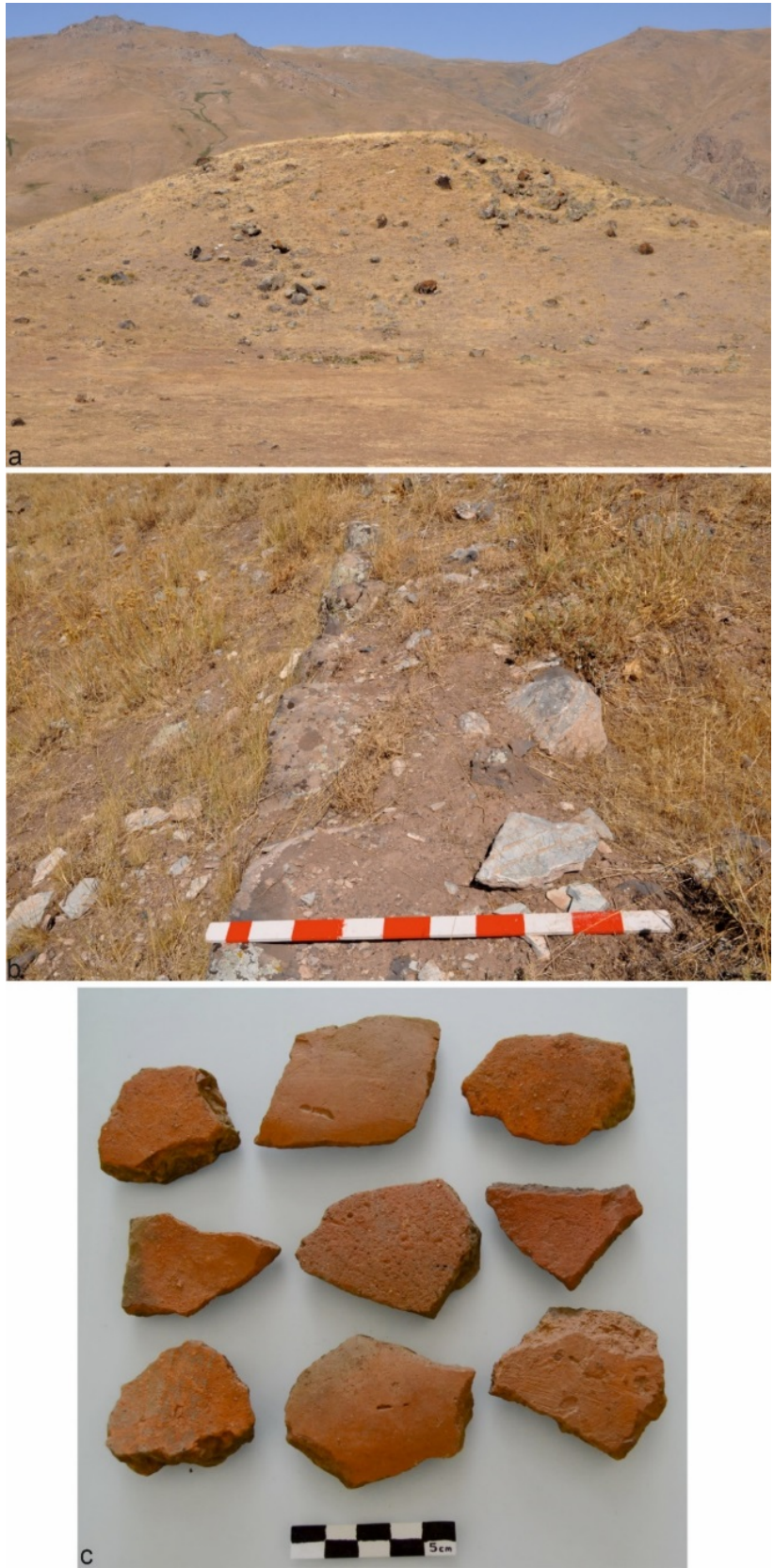

Fig. 8. Kuç Fortress: (a) general view of the natural hill where the fortress is located, (b) fortification wall remains, (c) examples of brick-red ware from the site. 


\section{Bilcan GÖKCE - Rıfat KUVANÇ- Bülent GENÇ}
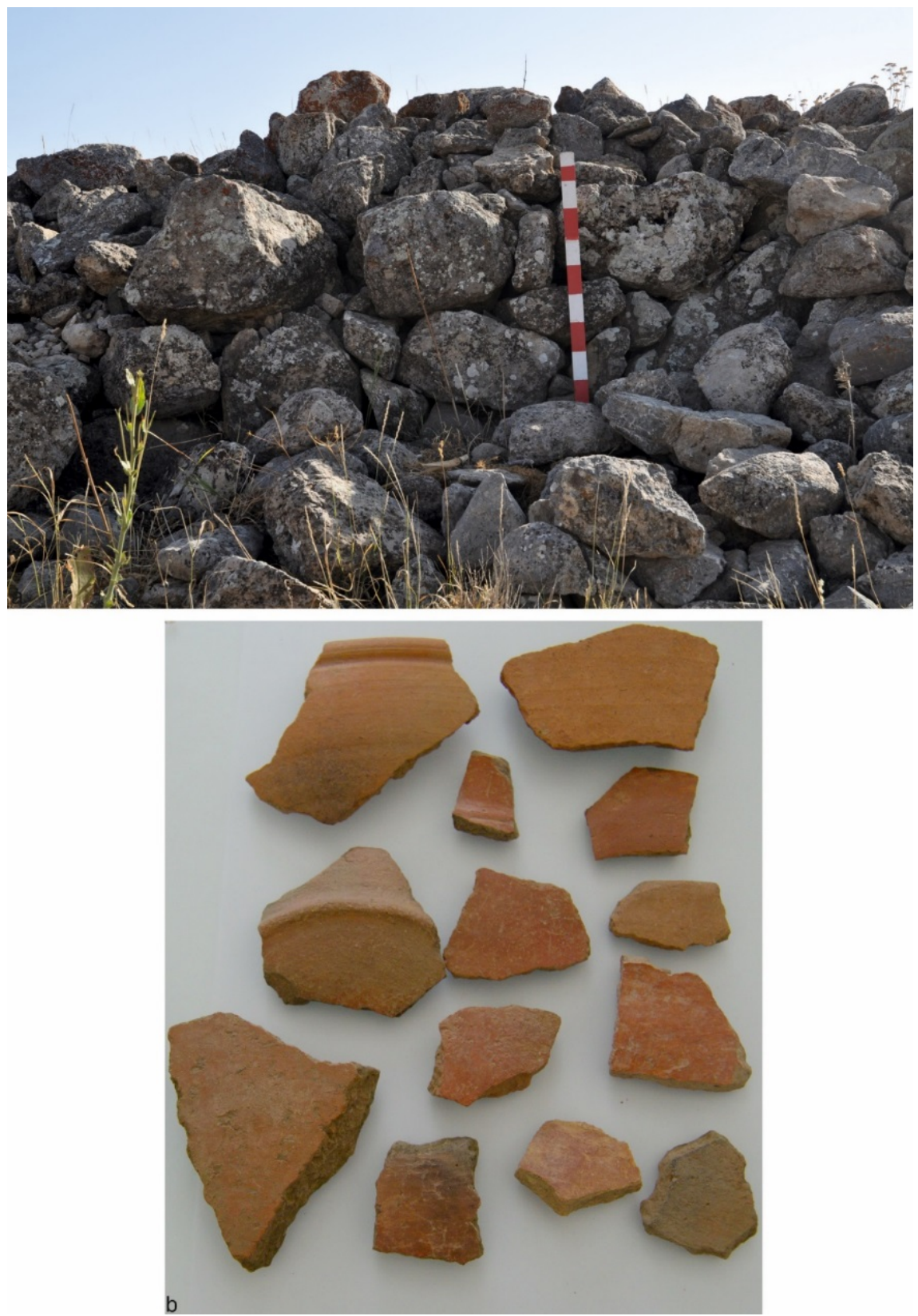

Fig. 9. Kelle Fortress: (a) fortification wall, detailed view of construction technique, (b) examples of ceramic sherds found at the fortress and in the vicinity. 

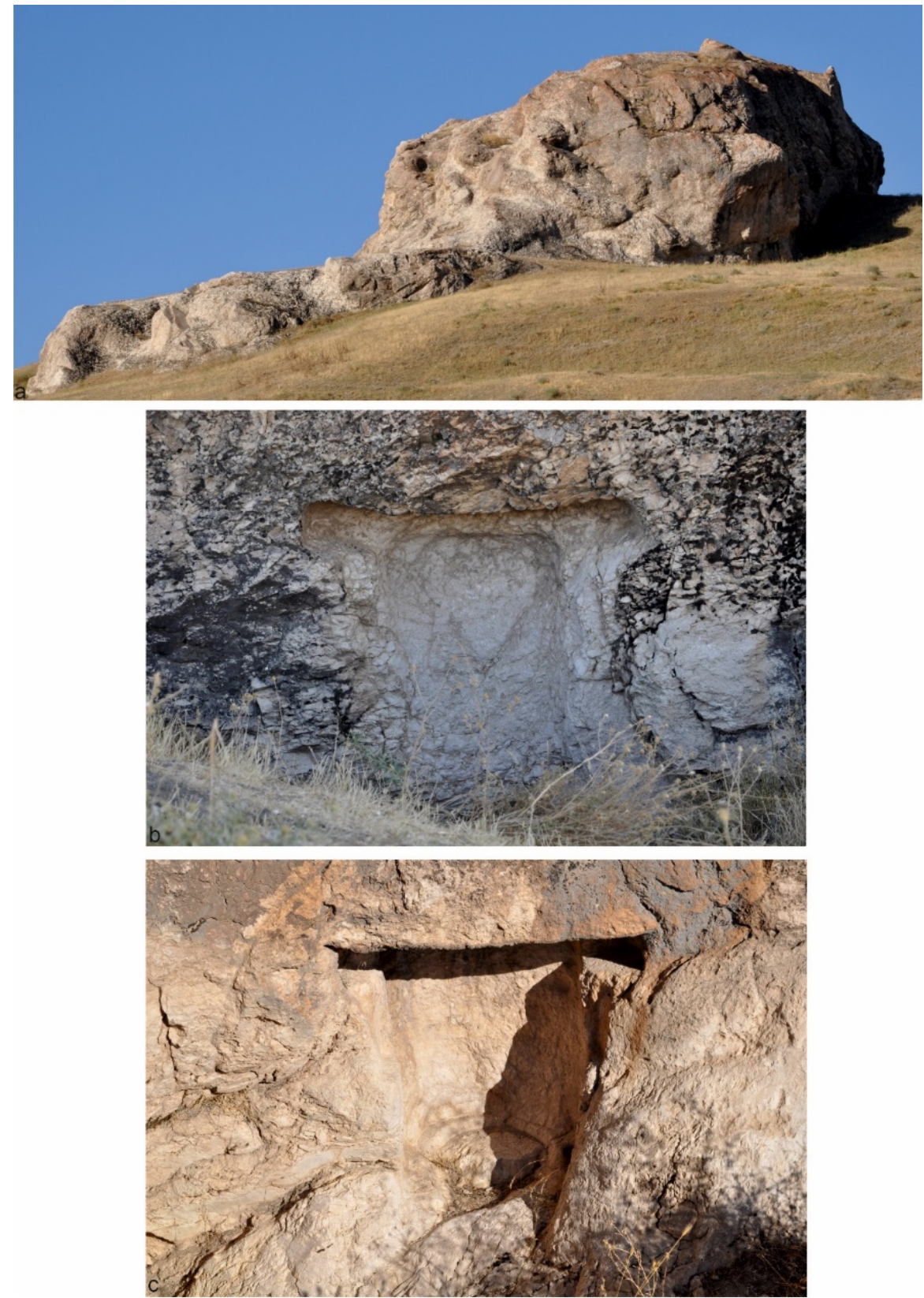

Fig. 10. Topaktaş locality: (a) view of rocky outcrop from east, (b) T-shaped niche on the southwest, (c) T-shaped niche on the southeast. 


\section{Bilcan GÖKCE - Rıfat KUVANÇ- Bülent GENÇ}
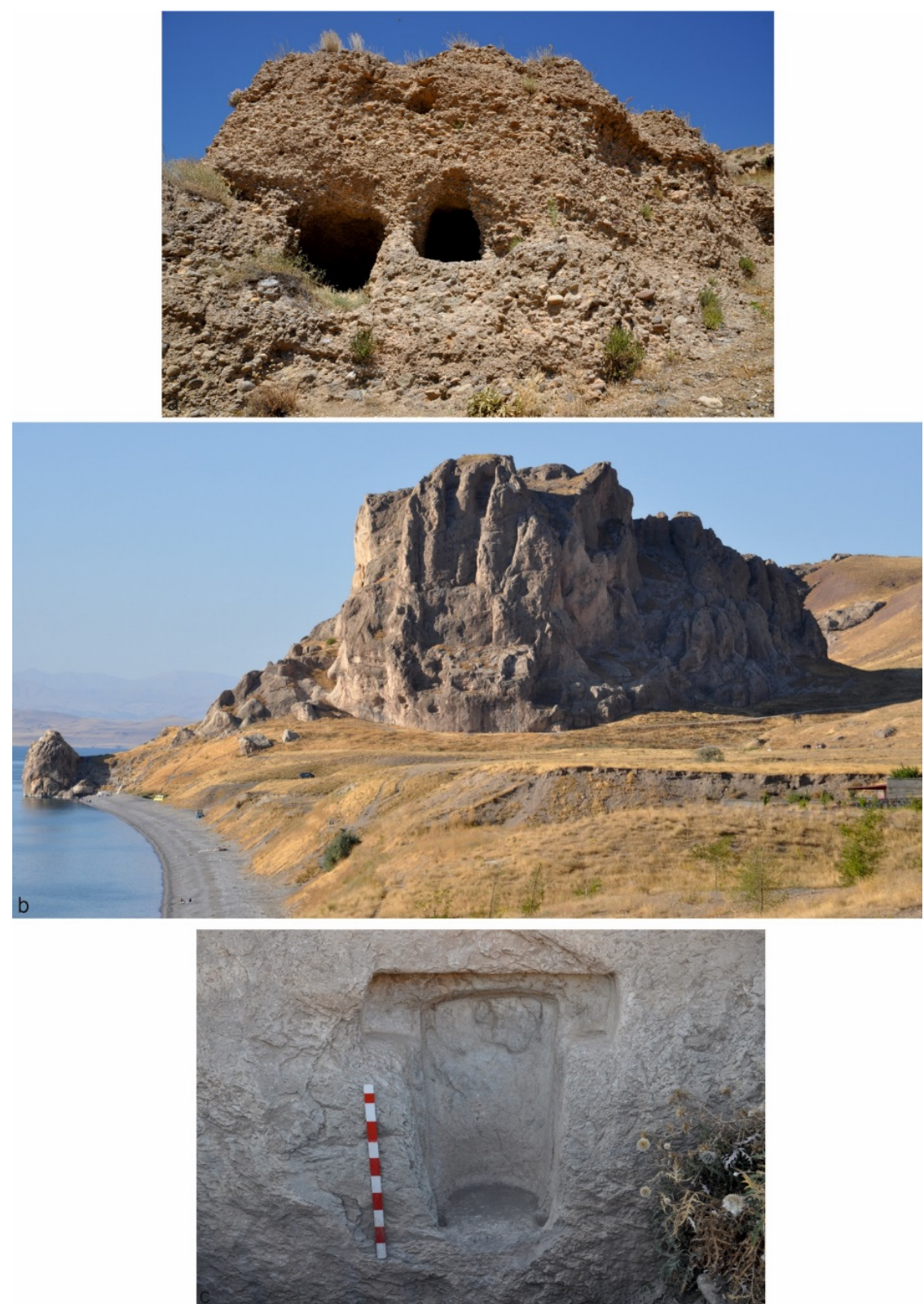

Fig. 11. Rock-cut tomb nearby Çarpanak Island: (a) rock-cut tomb façade, (b), Amik Fortress, (c) T-shaped niche carved into bedrock. 